О.Д. Шульга', Т.І. Мамчич ${ }^{2}$ ${ }^{1}$ Волинська обласна клінічна лікарня, Луцьк ${ }^{2}$ Східноєвропейський національний університет імені Лесі Українки, Луцьк

\title{
Проспективне 5-річне дослідження доброякісного розсіяного склерозу
}

Доброякісний розсіяний склероз (ДРС) включає тріаду критеріїв: легкий ступінь неспроможності з тривалістю захворювання > 10 років при збереженій працездатності. Мета - оцінити клінічні прояви у пацієнтів із ДРС протягом 5 років спостереження і розробити прогностичну модель ДРС. Об'єкт і методи дослідження. Проведене обсерваційне проспективне подвійне дослідження за участю 74 пацієнтів із ДРС. Оцінено клінічні прояви в динаміці та прогностичні фактори ДРС через 15 років захворювання. Результати. У пацієнтів групи сприятливого перебігу захворювання зі статистичною достовірністю на рівні $p<0,05$ перші симптоми розсіяного склерозу спостерігали в порівняно молодшому віці; також пацієнтам цієї групи захворювання діагностоване раніше. Вихідні показники балів за шкалою EDSS не були значущими. Висновки. Встановлено, що частка ДРС через 15 років становить 9,76\% усіх пацієнтів із розсіяним склерозом. Ключовими факторами є тип дебюту захворювання та вік пацієнта на час появи першого симптому. Розроблена прогностична модель перебігу розсіяного склерозу, побудована методом дискримінантного аналізу, дозволяє частково прогнозувати, до якої з груп імовірно потрапить пацієнт через 5 років.

Ключові слова: доброякісний розсіяний склероз, прогноз.

\section{Вступ}

На розсіяний склероз (РС) хворіють >20 тис. дорослих українців (Міщенко Т.С. та співавт., 2014). На сьогодні жодна комбінація демографічних, генетичних, лабораторних чи радіологічних даних не може визначати перебіг РС від першого симптому захворювання. Незважаючи на те що захворювання має прогресуючий характер, серед когорти пацієнтів із РС наявна частка осіб з відносно сприятливим (доброякісним) перебігом захворювання.

Доброякісний РС (ДРС) характерний для пацієнтів, які після 10 років тривалості хвороби не мають обмежень в активності, $€$ працевлаштованими, однак в них можуть спостерігатися ті чи інші симптоми PC (Sayao A.L. et al., 2007; Hirst C. et al., 2009; Glad S.B. et al., 2010; Шульга О.Д., 2016). При цьому судження щодо критеріїв ДРС залишаються дискутабельними. Так, більш «жорсткіші» критерії передбачають стаж хвороби $>15$ років (Hirst C. et al., 2009), ступінь неспроможності за шкалою EDSS (Expanded Disability Status Scale) $\leqslant 2,0$ бала. На основі проведеного першого в Україні дослідження ДРС (Шульга О.Д., 2016) нами запропоновані критерії ДРС, що включали тріаду ознак: тривалість хвороби $>10$ років, збережену працездатність і ступінь неспроможності за шкалою EDSS $>4$ балів.

Встановлено, що частка ДРС у популяції Волинської області становить 12,59\%. Нами ініційоване проспективне дослідження цієї когорти пацієнтів терміном 5 років.

Мета - оцінити клінічні прояви у пацієнтів із ДРС через 5 років та розробити прогностичну модель ДРС.

\section{Об'єкт і методи дослідження}

Обсерваційне, проспективне, подвійне (пацієнт, дослідник) дослідження пацієнтів із ДРС проводиться в Україні вперше. У дослідження залучали пацієнтів із ДРС за такими критеріями:

- вік 18-55 років;

- PC діагностований відповідно до критеріїв McDonald 2010 p. з поправкою (Polman C.H. et al., 2011);

- відсутність будь-яких інших неврологічних, психічних захворювань чи будь-яких інших захворювань, що спричиняють вогнища в головному мозку;

- відсутність алкогольної чи наркотичної залежності;

- тривалість спостереження $\geqslant 5$ років;

- підписання пацієнтами добровільної інформованої згоди на участь у дослідженні.

Будь-який стан, що не підходив під критерії включення, вважали критерієм виключення.

Первинна точка:

- оцінити клінічні прояви у пацієнтів із ДРС у динаміці через 5 років.

\section{Вторинні точки:}

- встановити прогностичні фактори ДРС через 15 років;

- розробити прогностичну модель.

Для зменшення розбіжностей неврологічне обстеження проводив за шкалою EDSS один сертифікований спеціаліст.

Статистичний аналіз здійснено за допомогою програми «Microsoft Excel», «SPSS for Windows», використані стандартні описові статистики. Для аналізу категоріальних даних використовували $\chi^{2}$ Пірсона. Статистично значущими вважали результати при $p<0,05$. Для оцінки величини та спрямованості кореляційної залежності використовували коефіцієнт непараметричної кореляції Спірмена. Для різностороннього аналізу використовували однофакторний дисперсійний аналіз ANOVA. 3 метою розроблення прогностичної моделі використано дискримінантний аналіз.

Дослідження виконано з дотриманням основних положень «Правил етичних принципів проведення наукових медичних досліджень за участю людини", затверджених Гельсінською декларацією (1964-2013), ICH GCP (1996), Директиви EЕC від 24.11.1986 р. № 609, наказів Міністерства охорони здоров'я України від 23.09.2009 р. № 690, від 14.12.2009 р. № 944, від 03.08.2012 р. № 616 .

Дослідження схвалено Комісією з питань етики Волинської обласної клінічної лікарні.

\section{Результати та їх обговорення}

Дослідження проводили в три етапи.

у 2012-2013 рр. на основі електронного реєстру пацієнтів із РС у Волинській області із 338 хворих, які надали згоду, виділено когорту 80 (12,59\%) пацієнтів, які відповідали запропонованим критеріям ДРС (53 жінки та 27 чоловіків; співвідношення жінки:чоловіки 1,96:1). Пацієнти впродовж 5 років перебували динамічне спостереження. На етапі спостереження з дослідження вибули два пацієнти, які змінили країну проживання. Повторну оцінку пацієнтів із ДРС проведено у 2017-2018 рр. Оскільки три пацієнти досягли пенсійного віку і припинили професійну діяльність, а за одним пацієнтом втрачене спостереження, до аналізу з підрахунком показників включено 74 пацієнти.

Схематично етапи дослідження представлені на рис. 1

Із 74 пацієнтів жінок було 48, чоловіків - 26 (співвідношення 1,84:1). Середній вік пацієнтів становив $46,44 \pm 8,36$ року. Вік по-

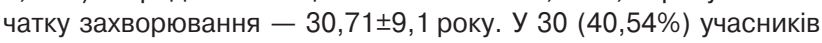
дослідження виявлено мультифокальний дебют РС. Динаміку балів за функціональними шкалами представлено у табл. 1, за шкалою EDSS - на рис. 2. 


\begin{tabular}{|c|c|c|c|c|}
\hline $\begin{array}{c}338 \text { пацієнтів } \\
\text { із PC } \\
\text { (2012-2013 рр.) }\end{array}$ & $\rightarrow$ & $\begin{array}{c}80 \text { пацієнтів } \\
\text { із ДРС } \\
\text { (2012-2013 рр.) }\end{array}$ & $\rightarrow$ & $\begin{array}{c}74 \text { пацієнти з ДРС } \\
\text { (2017-2018рр.) }\end{array}$ \\
\hline
\end{tabular}

Рис. 1. Етапи дослідження ДРС

Таблиця 1. Оцінка за функціональними шкалами пацієнтів із ДРС у динаміці Показники

\begin{tabular}{lccc}
\multicolumn{1}{c}{ Функціональна шкала } & \multicolumn{2}{c}{ Показники } & \\
\cline { 2 - 3 } & $\begin{array}{c}\text { на час } \\
\text { включення } \\
\text { у дослідження }\end{array}$ & $\begin{array}{c}\text { через } 5 \text { років } \\
\text { спостереження }\end{array}$ & $\mathbf{p}$ \\
Зорова & $0,85 \pm 0,83$ & $1,29 \pm 0,59$ & 0,0001 \\
Совбурова & $1,01 \pm 0,8$ & $1,23 \pm 0,65$ & 0,0356 \\
Пірамідна & $2,01 \pm 0,88$ & $2,31 \pm 0,77$ & 0,0038 \\
Мозочкова & $1,93 \pm, 62$ & $2,05 \pm 0,71$ & 0,1136 \\
Чутлива & $0,41 \pm 0,72$ & $0,90 \pm 0,7$ & 0,0000 \\
Тазова & $1,09 \pm 0,98$ & $1,45 \pm 0,84$ & 0,0069 \\
Церебральна & $1 \pm 0,74$ & $0,94 \pm 0,71$ & 0,2948 \\
Хода & $0,93 \pm 1,01$ & $1,52 \pm 2,08$ & 0,0120 \\
Загальний бал за шкалою EDSS & $3,05 \pm 0,85$ & $3,54 \pm 1,31$ & 0,0009 \\
\hline
\end{tabular}

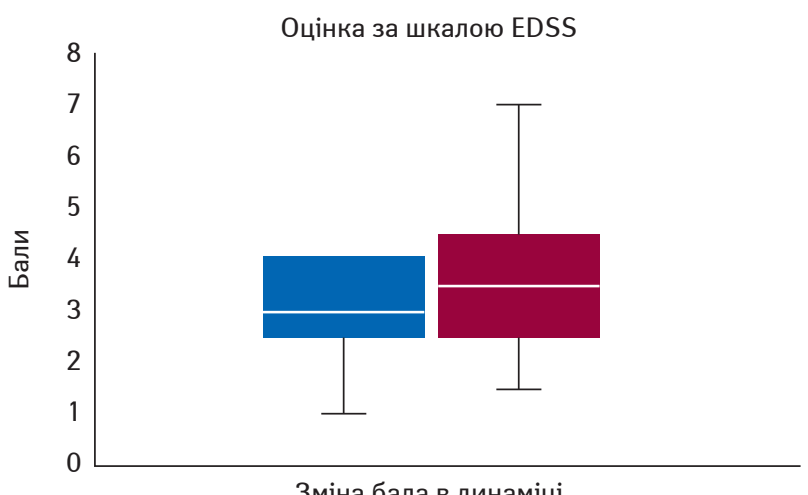

Рис. 2. Динаміка бала за шкалою EDSS.

Зліва - на момент включення у дослідження, справа - через 5 років спостереження.

3 метою оцінки факторів, що можуть впливати на прогноз захворювання, пацієнтів розподілено на дві групи:

- 1-ша - 33 пацієнти віком 44,15 8,40 року, які через 15 років тривалості захворювання відповідали критеріям ДРС;

- 2-га - 41 пацієнт віком 48,29 7,95 року, який через 15 років тривалості захворювання не відповідав критеріям ДРС.

У пацієнтів 2-ї групи зі статистичною достовірністю $(p<0,05)$ перші симптоми РС спостерігали порівняно в молодшому віці. Пацієнтам 1-ї групи захворювання діагностоване раніше. Вихідні показники балів за шкалою EDSS не виявилися значущими, однак оцінка за шкалою EDSS через 5 років спостереження суттєво відрізнялася між групами (табл. 2).

Таблиця 2. Основні характеристики досліджуваних

\begin{tabular}{lccc}
\hline \multicolumn{1}{c}{ Показник } & \multicolumn{2}{c}{ Група } & \multirow{2}{*}{$\mathbf{~}$} \\
\cline { 2 - 3 } & 1-ша & 2-га & \\
\hline Biк на час встановлення діагнозу, роки & $28,6 \pm 9,18$ & $31,41 \pm 8,78$ & 0,033953 \\
Biк на час дебюту, років & $23,57 \pm 9,18$ & $28,51 \pm 8,53$ & 0,008499 \\
EDSS на момент включення & $2,92 \pm 0,91$ & $3,15 \pm 0,78$ & 0,110581 \\
у дослідження, балів & & & \\
$\begin{array}{l}\text { EDSS чере3 5 років спостереження, } \\
\text { балів }\end{array}$ & $2,8 \pm 0,95$ & $4,13 \pm 1,27$ & 0,000000 \\
\hline
\end{tabular}

Методом однофакторного дисперсійного аналізу (ANOVA) досліджено залежності між приналежністю пацієнта до виділених нами груп та віком пацієнта, тривалістю хвороби, характеристикою початку захворювання, показниками за функціональними системами та бала за шкалою EDSS. Встановлено значущу залежність $(p<0,05)$ для показників віку хворого, віку на час першого симптому, перебігу дебюту РС, оцінки за такими функціональними системами: стовбуровою, пірамідною, мозочковою та чутливою. Також виявлено значущу залежність для фактора ходи.

Серед показників максимально «чутливими» до групуючого фактора були вік пацієнта, вік на момент першого симптому і тип дебюту РС.

Наступним кроком дослідження була спроба з'ясувати, чи можна було ще 5 років тому прогнозувати подальший перебіг хвороби, точніше, до якої з груп пацієнт мав би потрапити через 5 років при тому, що ми вже маємо теперішні результати. Нами використано метод дискримінантного аналізу. Дискримінантними показниками вибрано вік пацієнта на час першого симптому і тип перебігу захворювання. Показник «вік пацієнта» не використовували як частково дублюючий.

Мета дискримінантного аналізу - з'ясувати, чи дійсно існуючі групи розділяються на основі дискримінантних показників, та на основі отриманих даних побудувати прогностичну модель, яка за значеннями дискримінантних показників нових спостережень дозволить віднести їх до однієї з існуючихгруп. Щоб перевірити якість такої прогностичної моделі для заданих об'єктів, для яких вже відомагрупа, обчислюють прогнозовану групуі зіставляють з актуальною. В ідеальному випадку ці результати мають співпасти. Відсоткове співвідношення правильних та неправильних класифікацій за побудованою моделлю відображає її прогностичні можливості.

Результати дискримінантного аналізу свідчать, що дві групи значущо розділяються дискримінантними показниками на рівні $\mathrm{p}<0,02$.

Для двох груп визначено класифікуючі функції:

- $f_{1}=-6,134+4,033$ - тип дебюту + 0,248 · вік першого симптому;

- $f_{1}=-8,806+4,803 \cdot$ тип дебюту + 0,309 - вік першого симптому.

При цьому група ДРС через 15 років правильно класифікується у $74 \%$, а група з несприятливим PC - у $63 \%$ випадків. Для набору даних загалом виявлено 68\% правильних класифікацій.

щоб нове спостереження віднести до однієї з існуючих груп, потрібно значення його дискримінантних показників підставити в обидві класифікуючі функції та віднести його до тієї групи, яка з двох функцій набуде більшого значення.

У проведеному нами дослідженні наявні такі обмеження: не оцінювали рівень освіти респондентів (що може впливати на результати, враховуючи залежність працевлаштування від рівня освіти), залежність працевлаштування від типу спеціалізації, а також роль імуномодулюючої терапії.

Результати проведеного проспективного дослідження можуть бути використані неврологами в амбулаторній та стаціонарній роботі. Отримані дані доцільні для динамічного спостереженя пацієнтів із РC, а також у матеріалах роботи навчальних закладів.

\section{Висновки}

Проведено перше в Україні проспективне дослідження ДРС. Встановлено, що частка ДРС через 15 років становить 9,76\% усіх пацієнтів із РС. Виявлено, що ключовими факторами є тип дебюту PC і вік пацієнта на час першого симптому. Розроблена прогностична модель перебігу РС, побудована методом дискримінантного аналізу, дозволяє частково прогнозувати, до якої з груп імовірно потрапить пацієнт через 5 років.

\section{Конфлікт інтересів}

Автори заявляють про відсутність конфлікту інтересів.

\section{Список використаної літератури}

Міщенко Т.С., Шульга О.Д., Бобрик Н.В., Шульга Л.А. (2014) Розсіяний склероз: глобальні перспективи. Укр. мед. часопис, 3(101): 84-87 (https://www.umj.com.ua/article/75523).

Шульга О.Д. (2016) Доброякісний розсіяний склероз: критерії визначення, особливості перебігу. Укр. неврол. журн., 1: 85-88.

Glad S. B., Aarseth J.H., Nyland H. et al. (2010) Benign multiple sclerosis: a need for a consensus. Acta Neurol. Scand. Suppl., 190: 44-50.

Hirst C., Ingram G., Pickersgill T. et al. (2009) Increasing prevalence and incidence of multiple sclerosis in South East Wales. J. Neurol. Neurosurg. Psychiatry, 80(4): 386-391.

Polman C.H., Reingold S.C., Banwell B. et al. (2011) Diagnostic criteria for multiple sclerosis: 2010 revisions to the McDonald criteria. Ann. Neurol., 69(2): 292-302.

Sayao A.L., Devonshire V., Tremlett H. (2007) Longitudinal follow-up of «benign» multiple sclerosis at 20 years. Neurology, 68(7): 496-500.

\section{Проспективное 5-летнее исследование доброкачественного рассеянного склероза}

\section{О.Д. Шульга, Т.И. Мамчич}

Резюме. Доброкачественный рассеянный склероз (ДРС) включает триаду критериев: легкая степень несостоятельности сдлительностью заболевания >10 лет при сохраненной работоспособности. Цель оценить клинические проявления у пациентов с ДРС в течение 5 лет 
наблюдения и разработать прогностическую модель ДРС. Объект и методы исследования. Проведено обсервационное проспективное двойное исследование с участием 74 пациентов с ДРС. Оценивали клинические проявления в динамике ипрогностические факторы ДРС через 15 лет заболевания. Результаты. У пациентов групп благоприятного течения заболевания со статистической достоверностью на уровне $p<0,05$ первые симптомы PC отмечали в сравнительно более молодом возрасте; также пациентам этой группы диагноз заболевания установлен раньше. Исходные показатели баллов по шкале EDSS не были значимыми. Выводы. Установлено, что доля ДРС через 15 лет составляет 9,76\% всех пациентов с рассеянным склерозом. Ключевыми факторами являются тип дебюта заболевания и возраст пациента на момент появления первого симптома. Разработанная прогностическая модель течения рассеянного склероза, построенная методом дискриминантного анализа, позволяет частично прогнозировать, в какую группувероятно попадетпациент спустя 5 лет.

Ключевые слова:доброкачественный рассеянный склероз, прогноз.

\section{Prospective 5-year study of benign multiple sclerosis \\ O.D. Shulga, T.I. Mamchich}

Summary. Benign multiple sclerosis (BMS) includes a triad of criteria: medium disability with the duration of the disease for $>10$ years while maintain- ing working capacity. The aim - to evaluate clinical manifestations in patients with BMS during 5 years of follow-up and to develop a prognostic model of the BMS. Materials and methods. We conducted an observational, prospective, double-blind study of 74 patients with BMS. The clinical manifestations in the dynamics and the prognostic factors of the BMS in 15 years of the disease were evaluated. Results. In patients with a favorable disease course with statistical significance $(p<0.05)$ the first symptoms of multiple sclerosis were observed at a younger age; also the patients of this group have been diagnosed with the disease earlier. Output points on the EDSS scale did not appear to be significant. Conclusions. It was established that the proportion of BMS in 15 years is $9.76 \%$ of all patients with multiple sclerosis. It is found that the key factors are the type of multiple sclerosis debut and the patient's age at the time of the first symptom. The developed prognostic model of the flow of multiple sclerosis built by the method of discriminatory analysis allows partially to predict to which group the patient is likely to get after 5 years.

Key words: benign multiple sclerosis, prognosis.

Адреса для листування:

Шульга Ольга Дмитрівна

43000, Луцьк, просп. Президента Грушевського, 21

Волинська обласна клінічна лікарня

E-mail: shulgaolga@ukr.net

Одержано 30.01.2019 